\title{
Penerapan Metode Single Exponential Smoothing dalam Peramalan Penjualan Benang
}

\author{
Risqiati \\ Email : Risqiati24@gmail.com \\ STMIK Widya Pratama Pekalongan
}

\begin{abstract}
Abstrak
Ada banyak sekali persaingan dagang yang terjadi dalam penjualan benang. Makin banyaknya kompetitor yang ada membuat berbagai perusahaan harus siap dalam segala kemungkinan penjualan. Salah satunuya bagaimana bisa merubah kebiasan penjualan tanpa arah menjadi penjualan yang berkemungkinan baik. Salah satunya adalah dengan menggunakan teknik peramalan/forecasting dalam penjualan benang. Peramalan tentunya memberikan gambaran yang mendekati nilai sesunguhnya dalam penjualan yang akan datang. Ada beberapa teknik peralaman dalam penjualan, dari berbagai teknik yang ada dipilh metode single exponential smooting. metode ini adalah metode yang berfungsi untuk peramalan dalam waktu pendek dan merupakan metode time series yang bisa digunakan untuk peramalam bulanan. Walaupun dalam peramalan tidak akan akurat dalam keseluruhan, tetapi paling tidak memberikan gambaran tentang kemungkina penjualan yang ada. Keakuratan teknik sangat tergantung pada pilihan nilai konstanta pemulusan yang sesuai. Nilainya harus ditetapkan sedemikian rupa sehingga mengurangi kesalahan perkiraan Dalam penelitian ini didapatkan hasil nilai peramalan penjualan peramalan sebanyak 185 ball dengan nilai MAD 19, nilai MSE 1209 da nilai MAPE 8
\end{abstract}

Kata kunci : Benang, Peramalan, Single Exponential Smoothing

\section{Pendahuluan}

Dalam membuat kain yang baik ada beberapa faktor yang menentukannya, benang merupakan salah satu faktor penentu kualitas kain. Dengan mengunakan benang yang baik secara bentuk maupun secara komposisi, memungkinkan menghasilkan kualitas kain yang baik secara bentuk fisik maupun secara kualitas kain itu sendiri. Di lingkungan industry textile di kota Pekalongan, permintaan mengenai kualitas bentang yang baik merupakan tuntutan para produsen kain tenun di kota Pekalongan.

Salah satu industry benang yang ada di Pekalongan adalah PT.Hana Text berdiri pada tahun 2002, yang bergerak dalam penjualan benang sebagai suplayer untuk industi pemintalan kain baik khususnya kain kasa untuk kesehatan. Ada banyak faktor yang menyebabkan kain kasa dikatakan sebagai kain yang baik. Seperti kandungan air, kekuatan serat, bentuk fisik benang yang tidak berdebu, daya renggang benang, kandungan cotton yang ada di benang tersebut, serta benang yang bebas dari bakteri [1]. Oleh karena itu tidak akan menghasilkan kain yang baik, bila komposisi benang yang ada tidak mencakup standar kualitas yang baik pula.

Dalam perjalanan bisnisnya, PT. Hana Text memasarkan benang menggunakan cara pemasaran secara asal asalan, artinya hanya mengandalkan pemasaran sesuai dengan pemesanan dari calon konsumen melakui telpon ataupun mengajukan contoh benang kepada industry pembuatan kain kasa yang kemudian apabila cocok maka akan dilakukan transaksi secara cash. Selama ini cara pemasaran tersebut memiliki kelemahan bahwa penjual harus menunggu segala kemungkinan keputusan calon pembeli, yang bisa saja kemungkinan terjadinan proses jual beli benang ini kecil. Disamping itu persaingan penjualan benang cukup ketat seperti harga menjadi faktor yang sangat sensitive. Permasalahan yang ada adalah belum adanya system penjualan benang yang lebih tersturktur dan lebih terjadwal. Bila perusahaan tidak membuat perencanaan dalam memproduksi atau dalam proses menjual produknya, bisa dipastikan perusahaan tersebtu tidak akan mengontrol biaya yang timbul atas kejadian yang tidak diingnkan atau perusahaan tersebut tidak dapat meminimalkan biaya yang terbuang dalam satu bulan produksi. Bahan baku adalah salah satu item terpenting di system produksi yang keberadaannya perlu dikontrol demi proses produksi yan g lancar, menurut Bhattacharyya dan Sengupta (2011).

Permasalahan lain yang sering dihadapi adalah mengalami kelebihan bahan baku benang, terkadang kelebihan bahan baku ini sering membuat kualitas benang menjadi buruk karena pengaruh lingkungan dan yang lainnya, seperti warna benang semakin memudar atau pun kadar air yang semakin tinggi. 
Permasalahan ini menyebabkan peningkatan biaya perawatan karena kelebihan bahan baku benang.

Saat ini perhitungan konvensional dan tanpa adanya peramalan atau proses perencanaan yang baik dan benar, menjadikan salah satu hal yang memperburuk pengeluraan biaya yang tidak diperkirakan, sehingga diperlukan suatu metode yang mampu memberikan penyelesaian terhadap masalah penjualan. Suatu perusahaan perlu merencanakan pembelian dan melakukan peramalan penjualan untuk mengendalikan biaya bahan baku [2]. Peramalan penjualan sangat dibutuhkan untuk meningkatkan nilai produk dan juga untuk meningkatkan jumlah produksi.

Peramalan adalah alat perencanaan yang dirancang untuk membantu manajemen memenuhi ketidakpastian masa depan berdasarkan data sebelumnya dan analisis tren. Hal ini dianggap penting dan merupakan informasi dasar yang diperlukan dalam perencanaan bisnis yang merupakan tulang punggung operasi suatu industry yang efektif. Peramalan (forecasting) adalah ilmu untuk memperkirakan kejadian di masa depan dengan melihat kondisi aktual sebelumnya (time series). Dalam literatur, kata peramalan digunakan dalam berbagai cara untuk memberikan perbedaan antara peramalan (pernyataan probabilistik hasil masa depan dengan model), prediksi (pernyataan tentang hasil masa depan berdasarkan logika), proyeksi (hasil masa depan berdasarkan skenario) dan prognosis (penilaian subjektif keadaan masa depan) [3]. Peramalan akan digunakan oleh perusahaan atau sisi manajemen operasional yang berguna dalam membuat perencanaan dalam hal kegiatan usaha dalam jangak waktu tertentu. Peramalan banyak digunakan di berbagai bidang antara lain bidang pendidikan untuk meramalkan penerimaan calon peserta didik ditahun berikutnya, bidang kesehatan untuk meramalkan penjualan obat, bidang penjualan untuk meramalkan penjualan barang di masa yang akan datang. Berdasarkan horizon waktu menurut Herjanto (2008: 84), peramalan dibagi menjadi 3 yaitu: peramalan jangka pendek, peramalan jangka menengah, peramalan jangka panjang.

\section{Metodologi Penelitian}

Dalam peramalan/forecasting penjualan, ada beberapa metode yang dapat digunakan seperti Dalam memperkirakan peramalan penjualan ada beberapa metode yang dapat digunakan seperti least square, regresi linier, regresi dan korelasi, moment, semi average, trend bebas atau dengan metode exponential smoothing. Tidak mungkin suatu ramalan akan benar-benar akurat. Ramalan akan selalu berbeda dengan permintaan aktual. Itulah yang disebut denagn kesalahan ramalah bila ada perbedaan antara ramalan dengan data yang actual. Dalam setiap peramalan tentunya tidak dapat dipisahkan dari kesalahan, namun sebisa mungin kecil sekali. Akan teapi jika nilai kesalahan itu sangat besar, ini adalah indikasi apakah teknk ramalan digunakan salah, atau teknik ini perlu disesuaikan dengan mengubah parameter.

Dalam penelitian ini metode yang digunakan adalah metode exponential smoothing yang berfugnsi untuk peramalan dalam waktu pendek dan merupakan metode time series yang bisa digunakan untuk peramalam bulanan. Adapun beberapa penelitian yang relevan dengan penerapan metode Single Exponential Smoothing, yaitu penelitian yang berhasil meneliti tentang perumusan industry penjualan di Bangladesh menggunakan metode Single Exponential Smoothing dengan menemukan nilai optimum Smoothing constant sebesar 0,9 [4]. Untuk memulai penelitian ini, ada bebarapa tahapan yang harus dilalui seperti pada diagram dibawah ini:

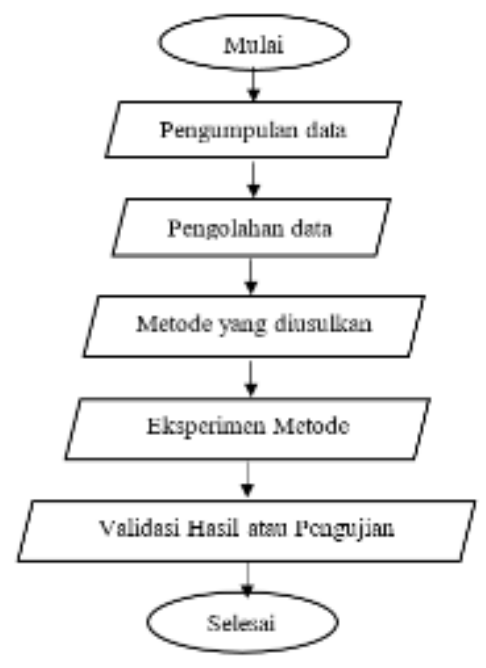

Gambar 1 Tahapan Penelitian 


\section{Hasil dan Pembahasan}

Observasi merupakan teknik yang lazim digunakan dalam pengumpulan data, yaitu dengan pengamatan di tempat penelitian dalam hal ini adalah PT. Hana. Dalam pengumpulan data ini, sejak awal sumber data yaitu perusahaan PT Hana Text, mengetahui bahwa akan diambil data secara private mengenai aktifitas perusahaan sampai terjadinya proses penjualan benang setiap bulannya.

Untuk mengetahui hal-hal yang lebih mendalam, juga digunakan teknik pengumpulan data dengan teknik wawancara, dengan maksud untuk mengetahui permasalahan yang lebih detail dari responden yang tidak terlihat jelas.

Studi literature (kajian pustaka) kajian analisa dokumen baik identifikasi, lokasi yang berkaitan beragam informasi mengenai permasalahan penelitian secara sistematis secara jelas dan logis. Penulis mencari dari perpustakaan dan jurnal yang berakitan dengan permasalahan yang ada.

Dalam Tahap ini pebeliti melakukan pengumpulan data transaksi penjualan benang pada PT. Hana Text antara bulan Januari 2021 sampai dengan Juni 2021.

Ada beberapa cara untuk mengolah data, salah satunya adalah menggunakan metode pengolahan data pada penelitian ini menggunakan metode analisis statis diskriptif . Statistic deskriptif adalah statistik yang digunakan untuk menganalisa data dengan cara mendeskripsikan atau menggambarkan data yang telah terkumpul sebagaimana adanya tanpa bermaksud membuat kesimpulan yang berlaku untuk umum ataun generalisasi [5]. Untuk proses pengolahan data, yaitu menentukan nilai peramalan pada bulan Januari 2020 yaitu nilainya sama dengan jumlah penjualan pada bulan Januari 2020 yaitu berjumlah 150 ball. Sedangkan untuk menganalisa kualitatifnya menggunakan metode single eksponensial smoothing, mean squared error (MSSE), mean absolute deviation serta mean absolute percent error (MAPE).

Ada dua jenis pendekatan peramalan: kualitatif dan kuantitatif. Beberapa teknik perkiraan mencoba untuk memproyeksikan pengalaman sejarah ke masa depan dalam bentuk deret waktu. Metode peramalan eksponensial tunggal merupakan salah satu peramalan deret waktu yang cocok untuk peramalan data tanpa tren atau pola musiman. Metode yang diusulkan dalam penelitian ini adalah single exponential smoothing. Single exponential smoothing adalah metode peramalan untuk jarak pendek yang biasanya untuk memperkirakan satu atau beberapa bulan ke depan. Sebenarnya metode ramalan exponential smoothing (penghalusan exponensial) adalah suatu metode rata-rata bergerak yang menghasilkan bobot lebih kuat pada data terakhir dibandingkan dengan data pada awal. Pemberian bobot ini berdasarkan pada besar nilai $\alpha$ (alpha) yang bisa ditentukan dengan secara acak antara nilai 0 sampai nilai 1. Kadang kala ada perubahan data yang mana merupakan perubahan actual (seperti pola musiman) menjadi hal yang sangat berguna daripada perubahan fluktiasi acak saja.

Untuk rumus perhitungan single exponential smoothing :

$F t+1=\alpha * X t+(1-\alpha) * F t-1$

Dimana :

$\mathrm{Ft}+1=$ Peramalan baru untuk periode ke $\mathrm{t}+1$

$\mathrm{Xt}=$ Nilai riil periode ke $\mathrm{t}$

$\alpha=$ Nilai bobot yang menunjukan konstanta penghalusan $(0<\alpha<1)$

Ft-1 = Ramalan untuk periode ke $\mathrm{t}-1$

Sedangkan untuk menghitung nilai alpha $(\alpha)$ adalah dengan rumus :

$\alpha=2 /(\mathrm{n}+1)$

Dimana :

$\alpha=$ Nilai bobot yang menunjukan konstanta penghalusan $(0<\alpha<1)$

$\mathrm{n} \quad=$ Jumlah periode waktu

Proses perhitungan peramalan penjualan benang di PT. Hana Text menggunakan metode single exponential smoothing. Berikut tahapan menghitung peramalan benang di PT. Hana Text yang di jual ke pelanggan.

a. Perhitungan nilai $\alpha$ (alpha)

Bahwa nilai alpha yang digunakan untuk metode exponential smoothing adalah antara nilai 0 sampai dengan nilai 1 .

Untuk mengdapatkan nilai alpha, dengan rumus :

$\alpha=2 /(n+1)$

Dimana $\mathrm{n}$ adalah jumlah periode waktu

Jadi dengan data yang ada yaitu sejumlah 18 bulan, maka perhitungannya adalah :

$=2 /(18+1)$

$=0,1$ 
b. Perhitungan benang cotton

Contoh perhitungan untuk peramalan pada bulan Februari tahun 2020,

$$
\begin{aligned}
& F t+1=\alpha * X t+(1-\alpha) * F t-1 \\
& \mathrm{Ft}+1=(0,1 * 150)+((1-0,1) * 150) \\
& \mathrm{Ft}+1=15+(0,9 * 150) \\
& \mathrm{Ft}+1=15+135 \\
& \mathrm{Ft}+1=150
\end{aligned}
$$

Hasil perhitungan peramalan penjualan benang pada bulan Janauri 2020 sampai dengan Juli 2021 dengan nilai bobot $\alpha$ (alpha) 0,1 , dapat dilihat seperti pada tabel

\begin{tabular}{|c|c|c|}
\hline BULAN & $\begin{array}{l}\text { JUMLAH } \\
\text { /Ball }\end{array}$ & $\begin{array}{l}\text { PERAMALAN } \\
\alpha=0,1\end{array}$ \\
\hline Januari 2020 & 150 & 150 \\
\hline Februari 2020 & 120 & 150 \\
\hline Maret 2020 & 135 & 147 \\
\hline April 2020 & 125 & 146 \\
\hline Mei 2020 & 150 & 144 \\
\hline Juni 2020 & 130 & 144 \\
\hline Juli 2020 & 200 & 143 \\
\hline Agustus 2020 & 210 & 149 \\
\hline September 2020 & 190 & 155 \\
\hline Oktober 2020 & 170 & 158 \\
\hline
\end{tabular}
1

Tabel 1. Hasil Peramalan penjualan benang cotton pada bulan Januari 2020 sampai Juli

$$
2021
$$

Untuk mengetahui nilai dari rata - rata nilai kesalahan menggunakan rumus Maka didapatkan hasil sebagai berikut :

Tabel 2. Hasil perhitungan kesalahan Peramalan

Untuk menghitung MAD dengan rumus :

$$
\begin{aligned}
& \text { MAD (Mean Absolute Deviation } \\
& =\sum \frac{\mid \text { Aktual }- \text { Peramalan } \mid}{n}
\end{aligned}
$$

maka nilai MAD dari nilai kesalahan peramalan adalah :

MAD = Jumlah Kesalahan Peramalan $/ \mathrm{n}$

\begin{tabular}{|l|l|l|}
\hline November 2020 & 230 & 159 \\
\hline Desember 2020 & 185 & 167 \\
\hline Januari 2021 & 210 & 168 \\
\hline Februari 2021 & 230 & 173 \\
\hline Maret 2021 & 205 & 178 \\
\hline April 2021 & 190 & 181 \\
\hline Mei 2021 & 195 & 182 \\
\hline Juni 2021 & 200 & 183 \\
\hline Juli 2021 & $\mathbf{?}$ & 185 \\
\hline
\end{tabular}

Untuk menghitung rata-rata kesalahan mutlak atau absolut digunakan perhitungan mean absolute deviation (MAD). Dengan kata lain MAD adalah cara untuk menunjukan beragam variasi yang ada dalam kumpulan data. Selain itu MAD juga dapat membantu kita dalam memahami bagaimana penyebaran nilai-nilai yang ada dalam sebegitu banyak data. Untuk menghitung tracking signal digunakanlah metode Mean Absolute Deviation (MAD), ini berguna untuk memastikan bahwa metode peramalan yang digunakn itu berguna atau tidak sama sekali. Untuk menghitung kesalahan dari peramalan menggunakan rumus

Kesalahan Peramalan $=A t-F t$ )

Dimana :

At $=$ Permintaan Aktual

$\mathrm{Ft}=$ Nilai Peramalan 
$\mathrm{MAD}=348 / 18$

$\mathrm{MAD}=19$

\begin{tabular}{|c|c|c|c|}
\hline Bulan & Jumlah/Ball & Peramalan & $\begin{array}{l}\text { Kesalahan } \\
\text { Peramalan }\end{array}$ \\
\hline $\begin{array}{c}\text { Januari } \\
2020 \\
\end{array}$ & 150 & 150 & 0 \\
\hline $\begin{array}{c}\text { Februari } \\
2020\end{array}$ & & 150 & 30 \\
\hline Maret 2020 & 135 & $\frac{150}{147}$ & -12 \\
\hline April 2020 & 125 & 146 & -21 \\
\hline Mei 2020 & 150 & 144 & 6 \\
\hline Juni 2020 & 130 & 144 & -14 \\
\hline Juli 2020 & 200 & 143 & 57 \\
\hline $\begin{array}{c}\text { Agustus } \\
2020 \\
\end{array}$ & 210 & 149 & 61 \\
\hline $\begin{array}{l}\text { September } \\
2020\end{array}$ & 190 & 155 & 35 \\
\hline $\begin{array}{c}\text { Oktober } \\
2020 \\
\end{array}$ & 170 & 158 & 12 \\
\hline $\begin{array}{l}\text { November } \\
2020\end{array}$ & 230 & 159 & 71 \\
\hline $\begin{array}{l}\text { Desember } \\
2020\end{array}$ & 185 & 167 & 18 \\
\hline $\begin{array}{c}\text { Januari } \\
2021\end{array}$ & 210 & 168 & 42 \\
\hline $\begin{array}{c}\text { Februari } \\
2021\end{array}$ & 230 & 173 & 57 \\
\hline Maret 2021 & 205 & 178 & 27 \\
\hline April 2021 & 190 & 181 & 9 \\
\hline Mei 2021 & 195 & 182 & 13 \\
\hline Juni 2021 & 200 & 183 & 17 \\
\hline
\end{tabular}

a. Perhitungan MSE

Mean Squared Error (MSE) adalah Rata-rata Kesalahan kuadrat diantara nilai aktual dan nilai peramalan. Metode Mean Squared Error secara umum digunakan untuk mengecek estimasi berapa nilai kesalahan pada peramalan. Apabila dari hasil perhitungan menunjukan nilai mean squared error yang rendah atau nilai mean squared error yang mendekati angka nol, itu menunjukkan bahwa hasil peramalan yang ada telah sesuai dengan data aktual perusahaan dan bisa dijadikan rujukan untuk perhitungan peramalan di masa yang akan datang. Untuk menghitung kesalahan, maka dengan rumus sebagai berikut :

\section{Kesalahan $=(\text { kesalahan peramalan })^{2}$}

Maka didapatkan hasil sebagai berikut :

Tabel 3. Hasil perhitungan kesalahan ${ }^{2}$

\begin{tabular}{|l|r|r|r|r|}
\hline Bulan & $\begin{array}{l}\text { Jumlah/ } \\
\text { Ball }\end{array}$ & $\begin{array}{l}\text { Peramal } \\
\text { an }\end{array}$ & $\begin{array}{l}\text { Kesalahan } \\
\text { Peramalan }\end{array}$ & $\begin{array}{l}\text { Kesalaha } \\
\mathbf{n}^{2}\end{array}$ \\
\hline $\begin{array}{l}\text { Januari } \\
2020\end{array}$ & 150 & 150 & 0 & 0 \\
\hline $\begin{array}{l}\text { Februari } \\
2020\end{array}$ & 120 & 150 & -30 & 900 \\
\hline Maret 2020 & 135 & 147 & -12 & 144 \\
\hline
\end{tabular}

\begin{tabular}{|c|c|c|c|c|}
\hline April 2020 & 125 & 146 & -21 & 441 \\
\hline Mei 2020 & 150 & 144 & 6 & 36 \\
\hline Juni 2020 & 130 & 144 & -14 & 196 \\
\hline Juli 2020 & 200 & 143 & 57 & 3249 \\
\hline $\begin{array}{l}\text { Agustus } \\
2020\end{array}$ & 210 & 149 & 61 & 3721 \\
\hline $\begin{array}{l}\text { September } \\
2020\end{array}$ & 190 & 155 & 35 & 1225 \\
\hline $\begin{array}{l}\text { Oktober } \\
2020\end{array}$ & 170 & 158 & 12 & 144 \\
\hline $\begin{array}{l}\text { November } \\
2020\end{array}$ & 230 & 159 & 71 & 5041 \\
\hline $\begin{array}{l}\text { Desember } \\
2020\end{array}$ & 185 & 167 & 18 & 324 \\
\hline $\begin{array}{l}\text { Januari } \\
2021 \\
\end{array}$ & 210 & 168 & 42 & 1764 \\
\hline $\begin{array}{l}\text { Februari } \\
2021\end{array}$ & 230 & 173 & 57 & 3249 \\
\hline Maret 2021 & 205 & 178 & 27 & 729 \\
\hline April 2021 & 190 & 181 & 9 & 81 \\
\hline Mei 2021 & 195 & 182 & 13 & 169 \\
\hline Juni 2021 & 200 & 183 & 17 & 289 \\
\hline
\end{tabular}

Untuk menghitung MSE dengan rumus :

$$
\begin{aligned}
& M S E=\left(\sum(\text { Kesalahan }) 2\right) / n \\
M S E= & 21702 / 18 \\
M S E= & 1206
\end{aligned}
$$

\section{b. Perhitungan MAPE}

Mean Absolut Percentage error (MAPE) adalah persentase kesalahan rata-rata secara multak atau absolut. Mean Absolute Percentage Error adalah suatu cara pengukuran statistik tentang akurasi perkiraan (prediksi) yang terjadi pada metode peramalan yang digunakan. Banyak dari masyarakat pada umumnya menggunakan pengukuran Mean Absolute Percentage Error (MAPE), sebab lebih mudah dipahami dan diterapkan untuk memprediksi akruasi peramalan. Metode Mean Abosolute Percentage Error (MAPE) memberikan informasi tentang seberapa besar nilai kesalahan peramalan yang terjadi jika dibandingkan dengan nilai sebenarnya dari series tersebut. Semakin kecil nilai presentasi kesalahan (percentage error) pada MAPE maka semakin akurat hasil peramalan tersebut. Untuk menghitung kesalahan persen mutlak rata-rata, maka dengan rumus :

$$
\begin{aligned}
& \text { Kesalahan persen mutlak rata - rata } \\
& \quad=(\text { kesalahan peramalan } \\
& - \text { aktual }) 100
\end{aligned}
$$

Maka didapatkan hasil sebagai berikut : 
Tabel 4 Hasil perhitungan kesalahan persen mutlak rata-rata

\begin{tabular}{|c|c|c|c|c|c|}
\hline Bulan & $\begin{array}{l}\text { Jumlah/ } \\
\text { Ball }\end{array}$ & $\begin{array}{l}\text { Peram } \\
\text { alan }\end{array}$ & $\begin{array}{l}\text { Kesa } \\
\text { laha } \\
\text { n } \\
\text { Pera } \\
\text { mala } \\
\text { n } \\
\end{array}$ & $\begin{array}{l}\text { Kesala } \\
\text { han }^{2}\end{array}$ & $\begin{array}{l}\text { Kesalaha } \\
\text { n Persen } \\
\text { Mutlak } \\
\text { Rata- } \\
\text { rata }\end{array}$ \\
\hline $\begin{array}{l}\text { Januari } \\
2020\end{array}$ & 150 & 150 & 0 & 0 & 0 \\
\hline $\begin{array}{l}\text { Februari } \\
2020\end{array}$ & 120 & 150 & -30 & 900 & -25 \\
\hline $\begin{array}{l}\text { Maret } \\
2020\end{array}$ & 135 & 147 & -12 & 144 & -9 \\
\hline $\begin{array}{l}\text { April } \\
2020\end{array}$ & 125 & 146 & -21 & 441 & -17 \\
\hline $\begin{array}{l}\text { Mei } \\
2020\end{array}$ & 150 & 144 & 6 & 36 & 4 \\
\hline $\begin{array}{l}\text { Juni } \\
2020\end{array}$ & 130 & 144 & -14 & 196 & -11 \\
\hline Juli 2020 & 200 & 143 & 57 & 3249 & 29 \\
\hline $\begin{array}{l}\text { Agustus } \\
2020\end{array}$ & 210 & 149 & 61 & 3721 & 29 \\
\hline $\begin{array}{l}\text { Septemb } \\
\text { er } 2020\end{array}$ & 190 & 155 & 35 & 1225 & 19 \\
\hline $\begin{array}{l}\text { Oktober } \\
2020\end{array}$ & 170 & 158 & 12 & 144 & 7 \\
\hline $\begin{array}{l}\text { Novemb } \\
\text { er } 2020\end{array}$ & 230 & 159 & 71 & 5041 & 31 \\
\hline $\begin{array}{l}\text { Desembe } \\
\text { r } 2020\end{array}$ & 185 & 167 & 18 & 324 & 10 \\
\hline $\begin{array}{l}\text { Januari } \\
2021\end{array}$ & 210 & 168 & 42 & 1764 & 20 \\
\hline $\begin{array}{l}\text { Februari } \\
2021\end{array}$ & 230 & 173 & 57 & 3249 & 25 \\
\hline $\begin{array}{l}\text { Maret } \\
2021\end{array}$ & 205 & 178 & 27 & 729 & 13 \\
\hline $\begin{array}{l}\text { April } \\
2021 \\
\end{array}$ & 190 & 181 & 9 & 81 & 5 \\
\hline $\begin{array}{l}\text { Mei } \\
2021 \\
\end{array}$ & 195 & 182 & 13 & 169 & 7 \\
\hline $\begin{array}{l}\text { Juni } \\
2021 \\
\end{array}$ & 200 & 183 & 17 & 289 & 8 \\
\hline
\end{tabular}

Untuk menghitung MAPE dengan rumus :

$$
\begin{aligned}
& \text { MAPE } \\
& =\left(\sum\right. \text { (kesalahan persen mutlak rata } \\
& - \text { rata }) / n \\
& M S E \quad=144 / 18 \\
& M S E \quad=8
\end{aligned}
$$

\section{Kesimpulan}

Dari penelitian ini dapat disimpulkan metode single exponential smoothing adalah salah satu teknik peramalan penting yang banyak digunakan digunakan oleh banyak organisasi untuk memprediksi peristiwa masa depan. Namun, kesulitan muncul sebagai nilai persentase error (konstanta smoothing) diambil secara acak. Keakuratan teknik sangat tergantung pada pilihan nilai konstanta pemulusan yang sesuai. Nilainya harus ditetapkan sedemikian rupa sehingga mengurangi kesalahan perkiraan.

Untuk nilai peramalan penjualan benang pada bulan juli 2021 menggunakan metode single exponential smoothing mendapatkan hasil peramalan sebanyak 185 ball dengan nilai MAD 19, nilai MSE 1209 da nilai MAPE 8

\section{Daftar Pustaka}

[1] Jia-Horng Lin, Bing-Chiuan Shiu, ChingWen Lou and Yuan-Jen Chang, "Design and Fabrication of Smart Diapers with Antibacterial Yarn," Journal of Healthcare Engineering, vol. Volume 2017, p. 9 pages, 2017.

[2] Christian Lois, Janny Rowena, Hendy Tannady, "Perencanaan dan Pengendalian Persediaan Bahan Baku dengan Lot Sizing Economic Order Quantity," Journal of Industrial Enggineering and Management Systems, Vols. Vol. 10, N0. 2, pp. 111-118, 2017.

[3] Bernhard Schauberger, Jonas Jagermeyr and Christoph Gornott, "A Systematic Review of Local to Regional Yield Forecasting Approaches and Frequently used Data Resources," European Journal of Agronomy, vol. Volume 120, 2020.

[4] C. L. Karmaker, "Determination of Optimum Smoothing Constant of Single Exponential Smoothing Method: A Case Study," International Journal of Research in Industrial Engeineering, Vols. Vol. 6, No. 3, pp. 184-192, 2017.

[5] Dewi Rosa Indah, Evi Rahmadani, "Sistem Forecasting Perencanaan Produksi dengan Metode Single Eksponensial Smoothing pada Keripik Singkong Srikandi di Kota Langsa," Jurnal Penelitian Ekonomi Akuntansi, Vols. Vol. 2, No. 1, pp. 10-18, 2018. 